\title{
Fatal intoxication with PMMA - a novel designer analogue of amphetamine
}

\section{Śmiertelne zatrucie PMMA - nową pochodną amfetaminy}

\author{
Barbara Potocka-Banaś ${ }^{\bowtie}$, Tomasz Janus, Sławomir Majdanik, Krzysztof Borowiak \\ Pomorski Uniwersytet Medyczny w Szczecinie, Zakład Toksykologii Klinicznej i Sądowej, al. Powstańców Wlkp. 72, 70-111 Szczecin \\ Pomeranian Medical University in Szczecin, Department of Clinical and Forensic Toxicology \\ $\triangle$ bpotocka@pum.edu.pl
}

\begin{abstract}
Introduction: New designer drugs of the amphetamine class like 4-methoxyamphetamine (PMA) and 4-methoxymethamphetamine (PMMA) elicit psychoactive effects in the central nervous system (CNS) by enhancing monoaminergic neurotransmission. These substances are substrates for neurotransmitter transporter proteins, and after binding with them they penetrate inside the cells. PMA and PMMA also reverse the transport of endogenic neurotransmitters and stimulate their increased release into the synaptic gap. PMMA has a weaker psychostimulating effect and a stronger hallucinogenic effect than PMA.
\end{abstract}

Materials and methods: The article presents the case of fatal PMMA intoxication in a 28-year-old man. The post-mortem forensic toxicological analysis of collected blood samples was performed using the LC/MS/MS technique. The analysis detected $213 \mathrm{ng} / \mathrm{mL}$ of amphetamine, $270 \mathrm{ng} / \mathrm{mL}$ of 3,4-methylenedioxymethamphetamine (MDMA, Ecstasy), and $4585 \mathrm{ng} / \mathrm{mL}$ of PMMA. Results: The cause of death was acute multiple organ failure resulting from heavy intoxication with psychoactive substances, particularly with PMMA.

Keywords: PMMA; fatal intoxication; LC/MS/MS.

\begin{abstract}
ABSTRAKT
Wstęp: Nowe pochodne amfetaminy, do których zaliczane są m.in. 4-metoksyamfetamina (PMA) i 4-metoksymetamfetamina (PMMA), wywierają działanie psychoaktywne poprzez nasilenie transmisji monoaminergicznej w ośrodkowym układzie nerwowym (OUN). Związki te stanowią substraty białek nośnikowych dla neuroprzekaźników, w związku z czym za ich pośrednictwem transportowane są do wnętrza komórek, odwracając jednocześnie kierunek transportu endogennych neuroprzekaźników, w wyniku czego dochodzi do ich nasilonego uwalniania do szczeliny synaptycznej. PMMA działa słabiej psychostymulująco oraz silniej halucynogennie niż PMA.

Materiały i metody: W pracy przedstawiono przypadek śmiertelnego zatrucia młodego, 28-letniego, mężczyzny na polu
\end{abstract}

kempingowym w nadmorskiej miejscowości. Z wywiadu środowiskowego wynika, że mężczyzna mógł zażywać bliżej nieokreślone środki psychoaktywne. Przeprowadzono badanie sądowo-toksykologiczne na materiale biologicznym (krew) zabezpieczonym w trakcie sądowo-lekarskiej sekcji zwłok, w którym stwierdzono obecność amfetaminy w stężeniu $213 \mathrm{ng} / \mathrm{mL}$, 3,4-metylenodioksymetamfetaminy (MDMA) w stężeniu $270 \mathrm{ng} /$ $\mathrm{mL}$, PMMA w stężeniu $4585 \mathrm{ng} / \mathrm{mL}(4,58 \mathrm{ug} / \mathrm{mL})$.

Wyniki: Na podstawie wyników badania sekcyjnego oraz badań dodatkowych za bezpośrednią przyczynę śmierci denata uznano ostrą niewydolność wielonarządową, do której doszło na skutek złożonego zatrucia substancjami psychoaktywnymi, a w szczególności PMMA.

Słowa kluczowe: PMMA; śmiertelne zatrucie; LC/MS/MS.

\section{INTRODUCTION}

In recent years in Poland and other European countries, a disturbing systematic increase in the number of new psychoactive substances (NPS), called designer drugs, has been observed. These substances are being sold e.g. over the Internet as 'bath salts' or 'plant fertilizers' $[1,2]$. These 'bath salts' contain biologically active synthetic cathinone derivatives, including 4-methylmethcathinone (4-MMC), 1-phenyl-2-(1-pyrrolidinyl)1-pentanone (PVP- $\alpha$ ), and 3,4-methylenedioxypyrovalerone (MDPV) [3].

Synthetic cathinone derivatives are structural analogues of cathinone (S-(-)-2-amino-1-phenylpropan-1-one). They are usually snorted or ingested, and easily cross the blood-brain barrier. Synthetic cathinones are strong inhibitors of proteins transporting monoamines from the synaptic gap into

the neuron (the dopamine transporter - DAT, norepinephrine transporter - NET, and serotonin transporter - SERT), but their selectivity for DAT, NET, and SERT varies considerably [4].

Less popular NPSs ('legal highs') are novel amphetamine derivatives, including 4-methoxyamphetamine (PMA) and 4-methoxymethamphetamine (PMMA). These substances are usually ingested. Their molecule consists of a phenylethylamine structure with an attached methyl group in the $\alpha$-position of the aliphatic chain. Because of the presence of the methyl group, PMA and PMMA have a lower affinity to monoamine oxidase (MAO), and as a result their biological half-life and activity are longer, compared to phenylethylamine [5].

The market for novel designer analogues of amphetamine is very different from the market for synthetic derivatives of cathinone. Amphetamine derivatives are rarely sold over the Internet as 'legal highs'. Drug users very often buy them by 
mistake, thinking that they are actually getting a tested psychoactive substance.

Novel amphetamine derivatives produce a psychoactive effect by enhancing monoaminoergic transmission in the central nervous system (CNS). These substances are substrates for neurotransmitter transporter proteins, and after binding with them they penetrate inside the cells. At the same time, they also reverse the transport of endogenic neurotransmitters and stimulate their increased release into the synaptic gap. Because of structural transformations, particularly the presence of substituents in the phenyl ring, the novel amphetamine derivatives have different affinities to specific transporter proteins, and therefore cause different symptoms when ingested. Similarly to synthetic derivatives of $\beta$-cathinone, the substances strongly stimulate the dopaminergic transmission and produce a strong psychoactive effect, and have a high addictive potential. On the other hand, substances with a stronger effect on the serotonergic system produce effects characteristic for empathogens, and are characterized by a lower addictive potential $[6,7]$.

PMMA is a substance structurally similar to PMA, and the substitution of the nitrogen atom with the methyl group increases its lipophilicity. PMMA elicits stronger hallucinogenic and weaker psychostimulating effects than PMA [8].

In Poland PMMA is scheduled as an I-P class psychotropic substance under the Act of 29 July 2005 on Counteracting Drug Addiction (consolidated text: Journal of Laws - Republic of Poland, 2012, item 124 as amended), which means its production, possession, marketing and trafficking is illegal [9].

Since the number of reports on intoxication with NPSs has been growing in recent years, the article presents the case of a fatal intoxication with PMMA.

\section{CASE SUMMARY}

The body of a 28-year-old man was found at a camping site in a seaside town in Poland. According to the accounts of witnesses before his death, the man had been behaved irrationally, his speech was sputtering, and it was impossible to establish logical contact with him. Information acquired from the social environment indicated that the man was probably taking unspecified psychoactive drugs.

\section{RESULTS}

Post-mortem examination carried out at the Department of Forensic Medicine of the Pomeranian Medical University revealed macroscopic features of the generalized congestion of internal organs, focal ischaemic changes in the myocardium, and cerebral and pulmonary oedema. Enlarged myocardium and liver were also found on inspection.

Histopathological examination of biopsy specimens taken post-mortem from dissected organs (after H\&E staining) revealed cerebral oedema and the presence of small haemorrhagic foci, signs of pulmonary congestion and oedema, minor scarring of the myocardium, and signs of multifocal fatty liver degeneration with local cholestasis.

At forensic autopsy, samples of biological material (blood) were also preserved for toxicology tests. PMMA was isolated from $500 \mu \mathrm{L}$ of blood mixed with $100 \mu \mathrm{L}$ of an in-house reference standard of methamphetamine-D5 (500 ng/mL solution) and $6 \mathrm{~mL}$ of chloroform. The sample was shaken for $3 \mathrm{~min}$ and then centrifuged for $5 \mathrm{~min}$ at $14000 \mathrm{rpm}$. Next, $5 \mathrm{~mL}$ of the chloroform layer was collected, $0.5 \mathrm{~mL}$ of water with formic acid was added, and the sample was shaken again for $3 \mathrm{~min}$ and centrifuged for $2 \mathrm{~min}$ at $14000 \mathrm{rpm}$. In the final step, $200 \mu \mathrm{L}$ of the aqueous layer was collected into a dedicated glass vial and $800 \mu \mathrm{L}$ of deionized water was added. The prepared sample was analysed by liquid chromatography tandem mass spectrometry (LC/MS/MS).

The chromatographic separation was done using a Nexera XR liquid chromatograph from Shimadzu (autosampler, binary pump, thermostatic control system for columns and samples, degassing unit), and a Chromolith ${ }^{\circledR}$ Performance RP-18e 100-2 mm HPLC column from Merck. Operating parameters were as follows: mobile phase: acetonitrile with $0.1 \% \mathrm{HCOOH}$ and water with $0.1 \% \mathrm{HCOOH}$; mode: gradient elution; flow rate 500 $\mathrm{uL} / \mathrm{min}$. For mass spectrometry we used a TripleTOF 5600+ system from AB Sciex, model QqTOF; with a DuoSpray ion source coupled with an automatic calibrant delivery system with an APCI capillary. Electrospray ionization (ESI) was done in the positive mode at $500^{\circ} \mathrm{C}$, and gas flow rate 40/50/30 (curtain). The following scan modes were used: MS/MSHR: 136.100/119.06119.11 (50) ms for amphetamine; 150.1/119.06-119.11 (50) ms for methamphetamine; 194.200/105.04-105.09 (50) ms for 3,4-methylenedioxymethamphetamine (MDMA); and 58; 121; 78; 59; 30 for PMMA. The in-house standard was methamphetamine-D5. The results were analysed using MultiQuant software.

The analysis of biological material (blood) carried out with the LC/MS/MS system revealed the presence of amphetamine (213 ng/mL), MDMA (270 ng/mL) and PMMA (4585 ng/mL; 4.58 $\mathrm{ug} / \mathrm{mL})$.

Based on the results of post-mortem examination, histopathological examination and toxicology analysis, the death of the young man was assumed to have been directly caused by acute multiple organ failure, which occurred as a result of a combined intoxication with psychoactive substances, in particular PMMA.

\section{DISCUSSION AND CONCLUSIONS}

Synthetic cathinones stimulate the CNS, which is manifested by increased psychomotor activity, euphoria, changes in perception, anorexia, and insomnia [10]. Adverse effects include cardiovascular symptoms (tachycardia, palpitations, chest pain, hypertension, myocarditis, cardiac arrest), psychiatric symptoms (irritability, aggression, panic attacks, anhedonia), and neurological symptoms (insomnia, convulsions, dilated pupils, paraesthesia). Gastrointestinal symptoms include nausea, 
vomiting and abdominal pain. Intoxication with synthetic cathinones is manifested by disorders of the cardiovascular system, autonomic nervous system, neuromuscular disorders and neuropsychiatric symptoms [11, 12, 13, 14]. According to literature, the psychoactive effects of synthetic cathinones occur within 15-45 min after dosing and persist for $2-7 \mathrm{~h}$, while the adverse effects may last for several hours to several days [1].

Most symptoms of intoxication with novel amphetamine derivatives are similar to the adverse effects of $\beta$-cathinone derivatives. The most important are disorders of the cardiovascular system, convulsions, strong psychomotor agitation and renal failure, often resulting from rhabdomyolysis, and liver failure. Intoxication with PMMA may cause symptoms of serotonin syndrome [8].

In drug addicts, intensified release of monoamines to the synaptic gap activates 2 processes leading to neurotoxicity and neurodegeneration. This can indirectly cause excitotoxicity due to increased glutamate signalling. Increased metabolism of the monoamines released into the synaptic gap results in the formation of reactive oxygen species that are responsible for oxidative stress, which consequently leads to neuronal damage [8].

PMMA is distributed in the form of tablets which may also contain MDMA. In the reported case this was confirmed by chemical and toxicological analysis which revealed the presence of PMMA and MDMA in the blood sample collected during forensic autopsy.

Subjects intoxicated with PMMA often present symptoms such as delirium, drowsiness, falls, loss of consciousness, coma, teeth grinding, trismus, tachycardia, disseminated intravascular coagulation, elevated skeletal muscle tone, painful muscle cramps, and hypothermia [8].

The presented case of fatal intoxication with PMMA was the 1st case confirmed at the Department of Clinical and Forensic Toxicology, Pomeranian Medical University in Szczecin during routine tests commissioned by law enforcement authorities. This suggests a lower popularity of novel amphetamine derivatives among drug users compared to synthetic derivatives of $\beta$-cathinone, which have more frequently been detected in routine toxicological analyses.

In the reported case, the symptoms of intoxication with PMMA, which occurred before the patient's death, were generally similar to those induced by other amphetamine derivatives. The identified histopathological changes are non-specific for intoxication with PMMA and are also observed in a number of intoxications with other narcotic substances, such as cocaine, or amphetamine and its derivatives [15].
Therefore, it is reasonable to postulate that forensic investigation of cases of intoxication with NPSs should include identification of the given substances in biological material using modern specific analytical techniques such as LC/MS/MS or SPME-GC-MS.

\section{REFERENCES}

1. Ayres TC, Bond JW. A chemical analysis examining the pharmacology of novel psychoactive substances freely available over the internet and their impact on public (ill) health. Legal highs or illegal highs? BMJ Open 2012;2:e000977.

2. European Monitoring Centre for Drugs and Drugs Addiction. Annual report 2010: the state of the drugs problem in Europe. Luxembourg: Publications Office of the European Union; 2010. http://www.emcdda.europa. eu/publications/annual-report/2010 (20.05.2019).

3. Schifano F, Albanese A, Fergus S, Stair JL, Deluca P, Corazza O, et al. Mephedrone (4-methylmethcathinone; 'meow meow'): chemical, pharmacological and clinical issues. Psychopharmacology (Berl) 2011;214(3):593-602.

4. Simmler LD, Buser TA, Donzelli M, Schramm Y, Dieu LH, Huwyler J, et al. Pharmacological characterization of designer cathinones in vitro. Br J Pharmacol 2013;168(2):458-70.

5. Blanckaert P, van Amsterdam J, Brunt T, van den Berg J, Van Durme F, Maudens K, et al. 4-Methyl-amphetamine: a health threat for recreational amphetamine users. J Psychopharmacol 2013;27(9):817-22.

6. Miliano C, Serpelloni G, Rimondo C, Mereu M, Marti M, De Luca MA. Neuropharmacology of new psychoactive substances (NPS): focus on the rewarding and reinforcing properties and cannabimimetics and amphetamine-like stimulants. Front Neurosci 2016;10:153.

7. Miller KJ, Anderholm DC, Ames MM. Metabolic activation of serotonergic neurotoxin para-chloroamphetamine to chemically reactive intermediates by hepatic and brain microsomal preparations. Biochem Pharmacol 1986;35(10):1737-42

8. Wojcieszak J. Związki psychostymulujące. In: Zawilska JB, Andrzejczak D, Wojcieszak W. „Dopalacze” i leki OTC - nowi gracze na scenie związków psychoaktywnych. Łódź: Uniwersytet Medyczny w Łodzi; 2016. p. 45-71.

9. Ustawa z dnia 29 lipca 2005 r. o przeciwdziałaniu narkomanii. Dz. U. Nr 179, poz. 1485.

10. Antonowicz JL, Metzger AK, Ramanujam SL. Paranoid psychosis induced by consumption of methylenedioxypyrovalerone: two cases. Gen Hosp Psychiatry 2011;33(6):640.e5-6.

11. Fullajtar M, Ferencz C. Designer drug induced psychosis. Neuropsychopharmacol Hung 2012;14(2):137-40.

12. Mugele J, Nañagas KA, Tormoehlen LM. Serotonin syndrome associated with MDPV use: a case report. Ann Emerg Med 2012;60(1):100-2.

13. Kelly JP. Cathinone derivatives: a review of their chemistry, pharmacology and toxicology. Drug Test Anal 2011;3(7-8):439-53.

14. Zawilska JB, Słomiak K, Wasiak M, Woźniak P, Massalski M, Krupa E, et. al. $\beta$-cathinones derivatives - a new generation of dangerous psychostimulant “designer drug”. Prz Lek 2013;70(6):386-91.

15. Vevelstad M, Øiestad EL, Bremer S, Bogen IL, Zackrisson AL, Arnestad M. Is toxicity of PMMA (paramethoxymethamphetamine) associated with cytochrome P450 pharmacogenetics? Forensic Sci Int 2016;261:137-47. 